\title{
Prevalence of Anaplasma marginale in Water Buffaloes (Bubalus bubalis) in the State of Uttar Pradesh, North India
}

\author{
Savita Bisen, Andleeb Aftab, K. Jeeva, D. Chandra, O.K. Raina
}

10.18805/IJAR.B-4765

\begin{abstract}
Background: Bovine anaplasmosis caused by Anaplasma marginale is highly endemic in tropical and sub-tropical regions of the world where it accounts for huge economic losses to the livestock sector. Approximately $30 \%$ of water buffalo (Bubalus bubalis) herds in India are located in Uttar Pradesh (U.P). However in India, most of the research studies on Anaplasma are focused on cattle whereas studies on this pathogen in water buffaloes have been neglected. Therefore, present investigation was undertaken for determining the prevalence of $A$. marginale infection in water buffaloes in U.P, North India.

Methods: In the current investigation during 2017-2019, the prevalence of $A$. marginale infection in 228 water buffaloes in three districts of North-West U.P was studied by microscopy and by nested-PCR amplification of major surface protein 5 (msp5) gene.

Result: Microscopic examination of blood smears of 228 water buffaloes revealed $7.89 \%$ animals positive for $A$. marginale. Conventional PCR of full length major surface protein 5 (msp5) gene detected $29.39 \%$ and nested-PCR amplification of this gene detected $64.0 \%$ of these animals as positive for $A$. marginale infection. A high incidence of the infection detected in this study area suggests that water buffaloes may serve as reservoir hosts of $A$. marginale and play a vital role in the spread of infection to other susceptible animals. However further studies are required on larger buffalo populations for determining the epidemiological status of anaplasmosis in these animals in India.
\end{abstract}

Key words: Anaplasma marginale, Buffaloes, msp5 gene, PCR.

\section{INTRODUCTION}

Anaplasma marginale, a tick-borne obligate intraerythrocytic rickettsia is one of the most common causative agent of bovine anaplasmosis worldwide and is endemic in several regions of Asia, Africa, Australia, North and South America (Kocan et al. 2010). The effects of bovine anaplasmosis on the health and productivity of cattle have been known since long but buffaloes, bison, African antelopes, mule deer can become persistently infected with $A$. marginale (Kuttler, 1984). The clinical symptoms of anaplasmosis include haemolytic anaemia, weight loss, high fever, tachycardia, jaundice, decreased milk yield, gastrointestinal signs, abortion and sudden death (Kocan et al. 2003, 2004).

Transmission of $A$. marginale in cattle and buffaloes occurs biologically through ticks and mechanically by bloodfeeding flies and blood contaminated fomites (Scoles et al. 2005). Transplacental transmission of $A$. marginale occurs in cattle, resulting in healthy but persistently infected calves (Kocan et al. 2015). Microscopic examination of stained blood smears is the conventional method for detecting $A$. marginale infection. However, molecular techniques and serological assays have proven to be more sensitive and specific for the detection of subclinical infection and carrier status of the animal for anaplasmosis (Bisen et al. 2021). Major surface proteins of $A$. marginale play a vital role in the interaction and invasion of the pathogen into the host cells. Six major surface proteins (MSPs) MSP1a, MSP1b, MSP2, MSP3, MSP4 and MSP5 have been identified and studied in $A$. marginale as promising molecules in the diagnosis and vaccine development (Palmer et al. 1985;
Division of Parasitology, ICAR- Indian Veterinary Research Institute, Izatnagar-243 122, Uttar Pradesh, India.

Corresponding Author: Savita Bisen, Department of Veterinary Parasitology, College of Veterinary Science and Animal Husbandry, Dau Shri Vasudev Chandrakar Kamdhenu Vishwavidyalaya, Anjora, Durg-491 001, Chhattisgarh, India. Email: bisen_savita@rediffmail.com

How to cite this article: Bisen, S., Aftab, A., Jeeva, K., Chandra, D. and Raina, O.K. (2022). Prevalence of Anaplasma marginale in Water Buffaloes (Bubalus bubalis) in the State of Uttar Pradesh, North India. Indian Journal of Animal Research. DOI: 10.18805/ IJAR.B-4765.

Submitted: 01-09-2021 Accepted: 08-11-2021 Online: 26-02-2022

Kocan et al. 2003, 2004; de la Fuente et al. 2010). Major surface protein 5 is a highly conserved surface protein that has been proven effective as a diagnostic antigen (de Echaide et al. 1998). India is a developing agricultural country and is the largest buffalo milk producer in the world. Buffaloes make an important contribution to the agricultural economy. According to $20^{\text {th }}$ livestock census (Department of Animal Husbandry and Dairying, Government of India, 2019); water buffalo population is 109.85 million which contributes to about $20.5 \%$ of the total livestock population of our country. Uttar Pradesh state has the largest water buffalo population, nearing 33 million (Department of Animal Husbandry and Dairying, Government of India, 2019). Like cattle, buffaloes are also susceptible to many tick-borne parasitic infections causing huge production and economic losses to the dairy farmers (Vidotto et al. 1998). Bovine 
anaplasmosis caused by $A$. marginale in cattle has been reported from several parts of India but there are meagre reports on its occurrence in water buffaloes in India. Therefore, present investigation on the prevalence of $A$. marginale infection in water buffaloes in U.P, North India by microscopy and by PCR was undertaken for determining the status of this infection in this part of the country.

\section{MATERIALS AND METHODS}

Blood samples of two hundred twenty eight water buffaloes were collected from Bareilly, Moradabad and Pilibhit districts of U.P from July 2017 to June 2019. Blood samples were collected from asymptomatic buffaloes and those with signs of fever, anaemia, tick infestation and reduced milk production for screening of Anaplasma marginale infection. The blood samples were collected from the ear vein and jugular vein of the animals. Thin blood smears were prepared by puncturing the ear vein using $18 \mathrm{G}$ needle, air dried and fixed in methanol for $2 \mathrm{~min}$. The thin blood smears were stained with a working dilution of $10 \%$ Giemsa stain for 40 min. The smears were washed with tap water, air dried and examined under oil immersion lens (X 100) of microscope for demonstration of $A$. marginale. Whole blood ( $\sim \mathrm{ml})$ was drawn from the jugular vein into EDTA coated vacutainers (BD, USA) and stored at $-20^{\circ} \mathrm{C}$ for isolation of genomic DNA. The present investigation was performed at the Division of Parasitology, ICAR-Indian Veterinary Research Institute, Izatnagar, Bareilly (U.P) from July 2017 to June 2019. The percentage rickettsia was determined by counting the infected RBCs in proportion to the total RBCs in at least 1520 microscopic fields. Percentage of rickettsia infected RBCs was determined using the following formula.

$$
\% \text { rickettsia }=\frac{\text { Total no. of infected erythrocytes }}{\text { Total no. of erythrocytes counted }} \times 100
$$

\section{Molecular detection of $\boldsymbol{A}$. marginale infection in water buffaloes}

Genomic DNA was isolated from $100 \mu$ l of whole blood from each sample using DNAeasy® blood and tissue kit (Qiagen, Germany) in accordance with the manufacturer's protocol. Extracted DNA was eluted in $50 \mu$ l of DNA elution buffer and stored at $-20^{\circ} \mathrm{C}$ till further use. The concentration of genomic DNA was quantified by Nanodrop spectrophotometer. Genomic DNA of $A$. marginale isolated from blood samples showing high parasitaemia by light microscopy was used as positive control in the PCR. Genomic DNA isolated from the whole blood of water buffaloes that were maintained in tick free conditions of the experimental sheds of ICAR-Indian Veterinary Research Institute, Izatnagar and were negative in the microscopic examination of several blood smears and in two rounds of nested-PCR were used as negative controls in PCR assays.

Blood samples from 228 water buffaloes belonging to the three districts of U.P were screened for $A$. marginale infection. The msp5 gene of $A$. marginale was used for the PCR amplification and for determining the prevalence of $A$. marginale infection in these animals. Primers were designed to amplify full length msp5 gene $(633 \mathrm{bp})$ of $A$. marginale as described by Visser et al. (1992) (Table 1) and custom synthesized based on GenBank accession number M93392. Each PCR reaction was carried out in a standard $25 \mu \mathrm{l}$ reaction volume using thermal cycler (S1000-BIO-RAD). The master mix used for the primary PCR reaction consisted of $2.5 \mu$ of $10 X$ PCR Green buffer (Thermo Scientific, USA), $0.5 \mu \mathrm{l}$ of $10 \mathrm{mM}$ dNTP mix (Thermo Scientific, USA), $0.25 \mu \mathrm{l}$ of Dream Taq DNA polymerase (Thermo Scientific, USA), $1.0 \mu \mathrm{l}$ each $(10 \mathrm{pmol})$ of the forward (msp5- FOR) and reverse (msp5-REV) primers (Eurofins, India) and $2.0 \mu \mathrm{l}$ of template DNA. The final volume was made up to $25 \mu \mathrm{l}$ using nuclease free water. Initial denaturation of the genomic DNA at $94^{\circ} \mathrm{C}$ for $4 \mathrm{~min}$ followed by 35 cycles of denaturation at $94^{\circ} \mathrm{C}$ for $45 \mathrm{sec}$, annealing at $52^{\circ} \mathrm{C}$ for $45 \mathrm{sec}$, primer elongation at $72^{\circ} \mathrm{C}$ for $1 \mathrm{~min}$ and final elongation at $72^{\circ} \mathrm{C}$ for 10 min was the protocol used for PCR amplification of the msp5 gene.

For enhanced sensitivity of the PCR assay, nested-PCR was also performed. Forward (msp5-N FOR-1) and reverse (msp5-N REV) primers were custom synthesized (Table 1) to amplify 457 bp fragment of msp5 gene. Subsequently, second round of nested-PCR was performed on this primary PCR product using internal forward (msp5-N FOR-2) and reverse (msp5-N REV) primers to amplify a product of 343 bp (de Echaide et al., 1998). The PCR reaction conditions were identical for carrying out conventional and nested-PCR. Primary PCR product (1:2 to $1: 10$ dilution) was used as template in nested-PCR. The PCR products were checked for amplification by electrophoresis on 1.5\% agarose gel and visualized in gel documentation system (Syngene, UK). A statistically significant number of PCR amplicons $(n=20)$ (both primary and nested-PCR products) were sequenced for confirmation of the Anaplasma species. Sensitivity of the nested-PCR was determined by tenfold dilution of the genomic DNA retrieved from the blood samples positive for

Table 1: Primers designed for conventional and nested-PCR for msp5 gene for identification of Anaplasma marginale infection in water buffaloes.

\begin{tabular}{llllc}
\hline Gene & Primer name & Primer length & Primer sequence $\left(5^{\prime} \rightarrow 3^{\prime}\right)$ & Amplicon size \\
\hline msp5 & msp5- FOR & $23 \mathrm{bp}$ & ATGAGAATTTTCAAGATTGTGTC & $633 \mathrm{bp}$ \\
& msp5- REV & $23 \mathrm{bp}$ & CTAAGAATTAAGCATGTGACCGC & \\
msp5-nested & msp5- N FOR-1 & $20 \mathrm{bp}$ & GCATAGCCTCCGCGTCTTTC & $457 \mathrm{bp}$ \\
& msp5- NREV & $20 \mathrm{bp}$ & TCCTCGCCTTGGCCCTCAGA & \\
& msp5- NFOR-2 & $21 \mathrm{bp}$ & TACACGTGCCCTACCGAGTTA & $343 \mathrm{bp}$ \\
\hline
\end{tabular}


A. marginale infection by microscopic examination. The specificity of the nested-PCR primers was also checked with genomic DNAs of Babesia bigemina, Theileria annulata and Trypanosoma evansi.

\section{RESULTS AND DISCUSSION}

The microscopic investigation of Giemsa stained peripheral blood smears of 228 water buffaloes detected 18 (7.89\%) animals positive for the blue/purple coloured, rounded inclusion bodies of $A$. marginale located at the margins of the erythrocytes. These results are in concurrence with the findings in South-West Gujarat where a prevalence of $7.07 \%$ of $A$. marginale infection was observed in water buffaloes by routine microscopy of Giemsa stained blood smears (Maharana et al., 2015). In the present investigation, 6.58\% $(15 / 228)$ of animals were found to be clinically infected and showed signs of pyrexia, progressive weakness, paleness of mucous membrane, tachycardia and tick infestation. The average level of parasitaemia in clinically positive animals was found as $1570.5 \pm 876.8 \times 10^{6}$ infected RBCs per $\mathrm{ml}$ of blood which coincided with the observations of Gale et al.
(1996). Rickettsiaemia level exceeding $10^{9}$ infected erythrocytes per $\mathrm{ml}$ of blood is indicative of acute infection, generally characterized by clinical manifestations. Recovery from acute anaplasmosis results in persistent infection and in such cases the level of rickettsiaemia is generally below the threshold levels of microscopic detection $\left(10^{6}\right.$ infected erythrocytes per $\mathrm{ml}$ of blood). Moreover, A. marginale organisms remain undetected during conventional microscopic investigation and microscopy is, therefore, not a reliable tool for detecting presymptomatic or carrier animals (Carelli et al., 2007; Aubry and Geale, 2011).

The PCR of the full length msp5 gene resulted in an amplicon of 633 bp in 29.39\% (67/228) of animals (Fig 1). However, nested-PCR was highly sensitive in the detection of rickettsia in buffaloes using primers designed by de Echaide et al. (1998). In the nested-PCR assay, A. marginale infection was revealed as the primary-PCR product of 457 bp in $35.5 \%(81 / 228)$ of buffaloes (Fig 2) while secondaryPCR generated amplicon of $343 \mathrm{bp}$ in $64.0 \%(146 / 228)$ of these animals (Fig 3). The analytical sensitivity of the PCR assay for detection of genomic DNA of $A$. marginale using

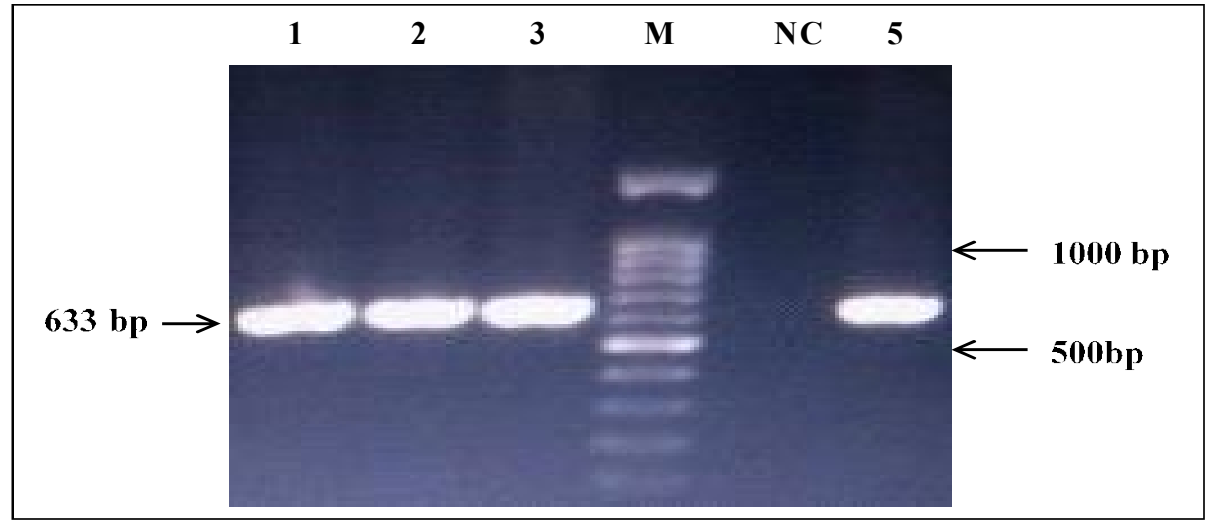

Fig 1: PCR amplification of full length msp5 gene of $A$. marginale in water buffaloes. Lane M: 100 bp DNA ladder.

Lanes 1, 2, 3, 5: PCR positive samples (633 bp).

Lane NC: No DNA template control.

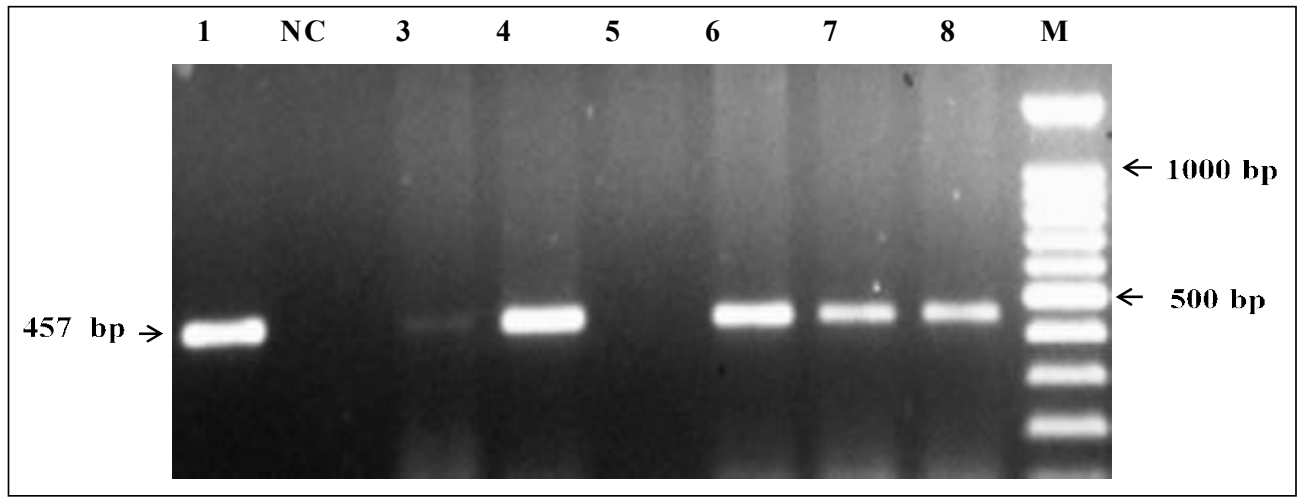

Fig 2: Nested-PCR (primary) amplification of $A$. marginale msp5 gene.

Lane M: 100 bp DNA ladder.

Lanes 1, 3, 4, 6, 7 and 8: msp5 PCR primary amplicon (457 bp).

Lane 5: PCR negative sample.

Lane NC: No DNA template control. 


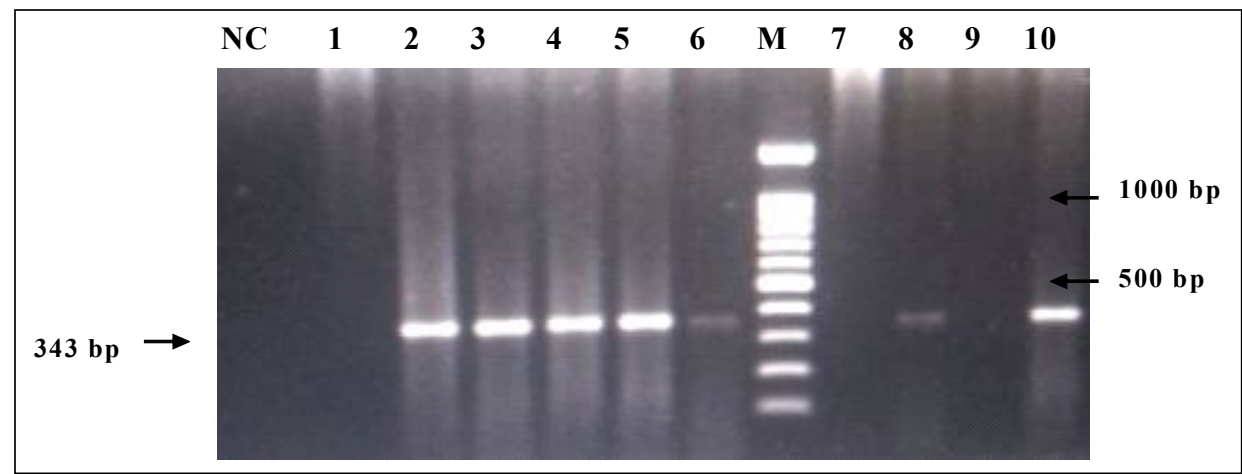

Fig 3: Nested-PCR (secondary) amplification of $A$. marginale msp5 gene.

Lane M: 100 bp DNA ladder.

Lanes 2, 3, 4, 5, 6, 8, 10: msp5 PCR secondary amplicon (343 bp).

Lane 1, 7, 9: PCR negative sample.

Lane NC: No DNA template control.

present set of primers was 200 picograms. A significant number of PCR amplicons $(n=20)$ were randomly sequenced which revealed nucleotide sequence specific to $A$. marginale. The PCR primers used in the present assay did not generate any amplicon when the genomic DNA of $T$. annulata, $B$. bigemina and $T$. evansi were used as template. Based on the msp5 gene PCR assay, the prevalence of $A$. marginale was reported to be $57.5 \%$ in buffaloes in Sri Lanka (Zhtldyz et al., 2019). In Colombia, a prevalence of $13.1 \%$ was observed in buffaloes using semi-nested PCR targeting the msp5 gene of $A$. marginale (James-Duenez et al., 2018). Molecular detection of $A$. marginale infection in buffaloes by PCR based on msp4 gene observed a prevalence of $8.0 \%$ in North-East Thailand (Saetiew et al. 2015). A study on buffaloes in Pakistan by Ashraf et al. (2013) using $16 \mathrm{~S}$ RNA gene reported a prevalence of $A$. marginale in $7.0 \%$ of animals. The nested-PCR based on msp5 gene has been reported as the most sensitive assay (de Echaide et al. 1998; Scoles et al. 2005; Singh et al., 2012; Mason et al., 2017; Bisen et al., 2021) for detecting A. marginale, A. centrale and $A$. ovis. Very few reports on the prevalence of $A$. marginale infection in water buffaloes are available from India. A three year old buffalo manifesting clinical signs of anaplasmosis and its complete recovery after treatment was reported by Vatsya et al. (2013). A prevalence of anaplasmosis in $18.18 \%$ $(4 / 22)$ buffaloes was reported by msp1 $\beta$ gene based PCR (Sharma et al. 2013). Based on the amplification of $576 \mathrm{bp}$ msp5 DNA, the detection rate of $A$. marginale was found to be $18.33 \%(11 / 60)$ in buffaloes in coastal South Gujarat (Kumar et al., 2019). A study on A. marginale using msp5 based nested-PCR observed a prevalence of $73.1 \%$ in carrier cattle of North-west India (Singh et al., 2012). Similar trends were observed in a study conducted in carrier cattle of North India which revealed a prevalence of $87.9 \%$ by nested-PCR based on msp5 gene of $A$. marginale (Bisen et al., 2021). In the present study, a large number of buffaloes found positive for anaplasmosis by microscopy and PCR were asymptomatic but only $6.58 \%$ of these buffaloes presented clinical signs of anaplasmosis. The clinical picture of $A$. marginale infection was revealed in only $1.90 \%$ of buffaloes in a study in coastal South Gujarat by Kumar et al. (2019). Buffaloes are reported to be less susceptible to A. marginale infection than cattle as they are naturally resistant to tick infestation and can reduce the intensity of infection by preventing the multiplication of the pathogen in the cells (Amira et al., 2020). Detection of persistently infected buffaloes and cattle is important to control the movement of infected animals into disease-free regions and also to formulate and implement strategic control measures against the spread of infection.

\section{CONCLUSION}

The present study carried out in water buffaloes in U.P, North India detected a large percentage of these animals as positive $(64.0 \%)$ for $A$. marginale by nested-PCR. However, a large buffalo population needs to be screened for anaplasmosis in different geographical regions of the country for a complete epidemiological study of the infection.

\section{Conflict of interests}

The authors declare that they have no conflict of interest.

\section{ACKNOWLEDGEMENT}

The authors are thankful to the Director ICAR-Indian Veterinary Research Institute, Izatnagar for providing necessary facilities for this research work. The authors acknowledge the grants received from CAAST/ACLHNAHEP (Grant No.NAHEP/CAAST/2018-2019) of ICARWorld Bank funded "National Agricultural Higher Education Project" for supporting this research work.

\section{REFERENCES}

Amira, A.L.H., Rãileanu, C., Tauchmann, O., Fischer, S., Nijhof, A.M. and Silaghi, C. (2020). Epidemiology and genotyping of Anaplasma marginale and co-infection with piroplasms and other Anaplasmataceae in cattle and buffaloes from Egypt. Parasites and Vectors. 13: 1-11. DOI: 10.1186/ s13071-020-04372-z. 
Prevalence of Anaplasma marginale in Water Buffaloes (Bubalus bubalis) in the State of Uttar Pradesh, North India

Ashraf, Q.U., Khan, A.U., Khattak, R.M., Ali, M., Shaikh, R.S. and Iqbal, F. (2013). A report on the high prevalence of Anaplasma sp. in buffaloes from two provinces in Pakistan. Ticks and Tick-Borne Diseases. 4: 395-398. DOI:10.1016/ j.ttbdis.2013.04.001

Aubry, P. and Geale, D.W. (2011). A review of bovine anaplasmosis. Transboundary and Emerging Diseases. 58: 1-30. DOI: 10.1111/j.1865-1682.2010.01173.x.

Bisen, S., Aftab, A., Jeeva, K., Silamparasan, M., Yadav, S., Chandra, D., Sankar, M., Garg, R. and Raina, O.K. (2021). Molecular and serological detection of Anaplasma infection in carrier cattle in north India. Veterinary Parasitology: Regional Studies and Reports. 24: 100550. DOI: 10.1016/j.vprsr. 2021.100550.

Carelli, G., Decaro, N., Lorusso, A., Elia, G., Lorusso, E., Mari, V., Ceci, L. and Buonavoglia, C. (2007). Detection and quantification of Anaplasma marginale DNA in blood samples of cattle by real-time PCR. Veterinary Microbiology. 124: 107-114. DOI: 10.1016/j.vetmic.2007.03.022.

de Echaide, ST., Knowles, D.P., McGuire, T.C., Palmer, G.H., Suarez, C.E. and McElwain, T.F. (1998). Detection of cattle naturally infected with Anaplasma marginale in a region of endemicity by nested PCR and a competitive enzyme-linked immunosorbent assay using recombinant major surface protein 5. Journal of Clinical Microbiology. 36: 777-782.

de la Fuente, J., Kocan, K.M., Blouin, E.F., Zivkovic, Z., Naranjo, V., et al. (2010). Functional genomics and evolution of tick-Anaplasma interactions and vaccine development. Veterinary Parasitology. 167: 175-186. DOI: 10.1016/ j.vetpar.2009.09.019.

Department of Animal Husbandry and Dairying (2019). Ministry of Fisheries, Animal Husbandry and Dairying, Government of India, $20^{\text {th }}$ Livestock census, key results (provisional). Krishi Bhawan, New Delhi.

Gale, K.R., Dimmock, C.M., Gartside, M. and Leatch, G. (1996). Anaplasma marginale: Detection of carrier cattle by PCRELISA. International Journal of Parasitology. 26: 11031109. DOI: 10.1016/S0020-7519(96)80009-9.

Kocan, K.M., de la Fuente, J., Guglielmone, A.A. and Melendez, R.D. (2003). Antigens and alternatives for control of Anaplasma marginale infection in cattle. Clinical Microbiology Reviews. 16: 698-712. DOI: 10.1128/CMR.16.4.698-712.2003.

Kocan, K.M., de la Fuente, J., Blouin, E.F. and Garcia-Garcia, J.C. (2004). Anaplasma marginale (Rickettsiales: Anaplasmataceae): recent advances in defining host-pathogen adaptations of a tick-borne rickettsia. Parasitology. 129: 285-300.

Kocan, K.M., de la Fuente, F., Blouin, E.F., Coetzee, J.F. and Ewing, S.A. (2010). The natural history of Anaplasma marginale. Veterinary Parasitology. 167: 95-107. DOI: 10.1016/j. vetpar.2009.09.012.

Kocan, K.M., de la Fuente, J. and Cabezas-Cruz, A. (2015). The genus Anaplasma: new challenges after reclassification. Revue Scientifique et Technique. 34: 577-586.

Kumar, N., Solanki, J.B., Varghese, A., Jadav, M.M., Das, B., Patel, M.D. and Patel, D.C. (2019). Molecular assessment of Anaplasma marginale in bovine and Rhipicephalus (Boophilus) microplus tick of endemic tribal belt of coastal South Gujarat, India. Acta Parasitologica. 64: 700-709. DOI: 10.2478/s11686-019-00041-z.
Kuttler, K.L. (1984). Anaplasma infections in wild and domestic ruminants: A review. Journal of Wildlife Diseases. 20: 1220. DOI: 10.7589/0090-3558-20.1.12.

Maharana, B.R., Kumar, B., Prasad, A., Patbandha, T.K., Sudhakar, N.R., Joseph, J.P. and Patel, B.R. (2016). Prevalence and assessment of risk factors for haemoprotozoan infections in cattle and buffaloes of South-West Gujarat, India. Indian Journal of Animal Research. 50: 733-739. DOI: $10.18805 /$ ijar. 10268.

Mason, K.L., Gonzalez, M.V., Chung, C., Mousel, M.R., White, S.N., Taylor, J.B. and Scoles, G.A. (2017). Validation of an improved Anaplasma antibody competitive ELISA for detection of Anaplasma ovis antibody in domestic sheep. The Journal of Veterinary Diagnostic Investigation. 29 : 763-766. DOI: $10.1177 \% 2 F 1040638717709494$.

Palmer, G.H., Kocan, K.M., Barron, S.J., Hair, J.A., Barbet, A.F., Davis, W.C. and McGuire, T.C. (1985). Presence of common antigens, including major surface protein epitopes, between the cattle (intraerythrocytic) and tick stages of Anaplasma marginale. Infection and Immunity. 50: 881-886.

Saetiew, N., Simking, P., Inpankaew, T., Wongpanit, K., Kamyingkird, K., Wongnakphet, S., Stich, R.W. and Jittapalapong, S. (2015). Prevalence and genetic diversity of Anaplasma marginale infections in water buffaloes in Northeast Thailand. The Journal of Tropical Medicine and Parasitology. 38: 9-16.

Scoles, G.A., Ueti, M.W. and Palmer, G.H. (2005). Variation among geographically separated populations of Dermacentor Andersoni (Acari: Ixodidae) in midgut susceptibility to Anaplasma marginale (Rickettsiales: Anaplasmataceae). Journal of Medical Entomology. 42: 153-162. DOI: 10.1093 /jmedent/42.2.153.

Sharma, A., Singla, L.D., Kaur, P., Bal, M.S., Batth, B.K. and Juyal, P.D. (2013). Prevalence and haemato-biochemical profile of Anaplasma marginale infection in dairy animals of Punjab (India). Asian Pacific Journal of Tropical Medicine. 6: 139-144. DOI: 10.1016/S1995-7645(13)60010-3.

Singh, H., Haque, M., Singh, N. K. and Rath, S. S. (2012). Molecular detection of Anaplasma marginale infection in carrier cattle. Ticks and Tick-Borne Diseases. 3: 55-58. DOI: 10.1016/j.ttbdis.2011.10.002.

Vatsya, S., Kumar, R.R., Singh, V.S. and Arunraj, M.R. (2013). Anaplasma marginale infection in a buffalo: A case report Veterinary Research International. 1: 51-53.

Visser, E.S., McGuire, T.C., Palmer, G.H., Davis, W.C., Shkap, V., Pipano, E. and Knowles, D.P.J. (1992). The Anaplasma marginale msp5 gene encodes a 19-kilodalton protein conserved in all recognized Anaplasma species. Infection and Immunity. 60: 5139-5144. DOI: 10.1128/iai. 60.12. 5139-5144.1992.

Vidotto, M.C., McGuire, T.C., McElwain, T.F., Palmer, G.H. and Knowles Jr., D.P. (1994). Intermolecular relationships of major surface proteins of Anaplasma marginale. Infection and Immunity. 62: 2940-2946.

Zhyldyz, A., Sivakumar, T., Igarashi, I., Gunasekara, E., Kothalawala, H., Silva, S.S.P. and Yokoyama, N. (2019). Epidemiological survey of Anaplasma marginale in cattle and buffalo in Sri Lanka. Journal of Veterinary Medical Science. 81: 1601-1605. DOI: 10.1292/jvms.19-0242. 